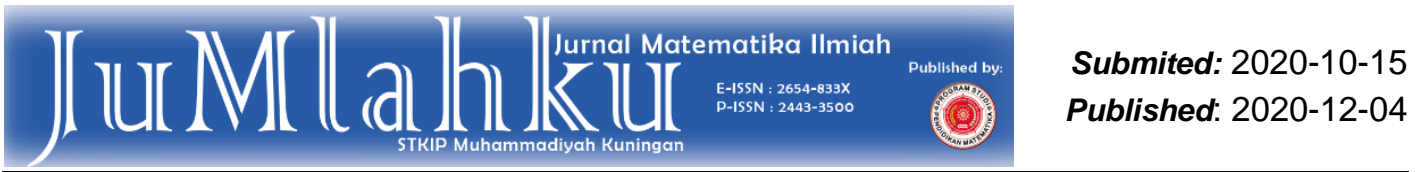

\title{
Analisis Konten Sumber Belajar Virtual Materi Statistika
}

Enika Wulandaria)

a) Program Studi Tadris Matematika, Fakultas Tarbiyah dan IImu Keguruan, IAIN Salatiga enika.wulandari@iainsalatiga.ac.id

$\frac{\text { Article Info }}{\text { Kaywords :content, virtual }}$ learning resources, statistics materials
Learning resources have a very important role in learning. Effective learning resources are learning resources that support the achievement of learning objectives. To determine the quality of learning resources, an analysis of the content of these learning resources is needed. The purpose of this study was to analyze the learning resource content of statistical materials in the form of videos used in virtual learning. The research was conducted at SMK Negeri 2 Salatiga. This research is a qualitative research conducted through case studies. The data were collected through a study of learning resources and interviews. Data were analyzed interactively. The results showed that (1) virtual learning resources for statistical materials were compiled based on direct instruction with steps to convey learning competencies, explain definitions and concepts, convey conceptual examples and their application and provide mathematical problems; (2) systematics of virtual learning resources, the introductory section contains greetings and information about the material, the core section contains a description of the competence of knowledge and skills to be achieved, material descriptions, examples of problem solving, mathematical problems in statistical material, the closing section contains information on competencies to be achieved in further learning, motivational sentences, and greetings; (2) the characteristics of the virtual learning resources of statistics material are contextual; 
Kata Kunci: konten, sumber belajar virtual, statistika

\section{PENDAHULUAN}

Guru Matematika selalu memiliki tantangan agar dapat menghadirkan pembelajaran yang efektif. Efektivitas pembelajaran dalam hal ini diukur dari ketercapaian tujuan pembelajaran.

Tantangan tersebut menjadi semakin semakin kompleks dalam konteks pembelajaran virtual yang dilaksanakan pada tahun 2020 ini. Dalam pembelajaran virtual, tidak adanya tatap muka antara guru dan siswa memunculkan kebutuhan akan sarana pembelajaran yang dapat memfasilitasi kegiatan belajar siswa tanpa kehadiran guru secara langsung.

\section{Abstrak}

Sumber belajar memainkan peran yang sangat penting dalam pembelajaran. Sumber belajar yang efektif merupakan sumber belajar yang mendukung ketercapaian tujuan pembelajaran. Untuk mengetahui kualitas sumber belajar diperlukan analisis mengenai konten sumber belajar tersebut. Tujuan penelitian ini adalah untuk menganalisis konten sumber belajar materi statistika berupa video yang digunakan dalam pembelajaran virtual. Penelitian dilaksanakan di ( statistika disusun berbasis model pembelajaran langsung (direct instruction) dengan langkah menyampaikan kompetensi pembelajaran, memaparkan definisi dan konsep, menyampaikan contoh konsep dan penerapannya serta memberikan masalah matematis; (2) sistematika sumber belajar virtual bagian pendahuluan memuat salam dan informasi mengenai materi, bagian inti berisi deskripsi kompetensi pengetahuan dan keterampilan yang akan dicapai, deskripsi materi, contoh penyelesaian masalah, masalah matematis pada materi statistika, bagian penutup berisi informasi kompetensi yang akan dicapai pada pembelajaran selanjutnya, kalimat motivasi, dan salam; kontekstual;
Pembelajaran virtual memerlukan sumber belajar yang dapat memfasilitasi pencapaian kompetensi yang diharapkan. Pengertian sumber belajar sebagaimana disampaikan oleh beberapa ahli yaitu Bambang, Sudjana, Mulyasa dan Association for Educational Communication and Technology (AECT), sumber belajar adalah suatu sistem yang terdiri dari sekumpulan bahan atau situasi yang diciptakan dengan sengaja agar siswa dapat belajar secara individual untuk memberikan kemudahan kepada siswa tersebut dalam belajar (Fitrah, 2015, p. 884). Definisi lain disampaikan oleh Purwanto bahwa sumber 
belajar adalah segala sesuatu yang dapat menyampaikan baik pesan maupun bukan pesan sehingga tujuan belajar dapat tercapai (Any, 2011, p. 3).

Dalam penelitian ini sumber belajar yang digunakan dalam pembelajaran virtual disebut dengan sumber belajar virtual. Sumber belajar memiki peran yang penting dalam pembelajaran. Sumber belajar turut mempengaruhi motivasi dan prestasi belajar siswa (Satriawan \& Wutsqa, 2013, p. 197). Hal ini berarti bahwa sumber belajar yang tepat akan mendukung pencapaian aspek afektif berupa motivasi dan aspek kognitif yaitu prestasi belajar matematika. Video merupakan salah satu pilihan yang tepat sebagai sumber belajar terutama pada pembelajaran virtual. Berkaitan dengan konsep yang abstrak, video pembelajaran berperan dalam mendeskripsikan secara konkret konsep tersebut melalui ilustrasi yang baik (Pamungkas et al., 2018, p. 130). Pernyataan tersebut menunjukkan bahwa video memiliki kegunaan dalam menjembatani antara konsep matematika yang bersifat abstrak dan pikiran siswa. Jaya menyatakan bahwa ada kebutuhan akan tersedianya video pengajaran dalam pertemuan virtual (Abdulloh et al., 2019, p. 34). Sumber belajar berupa video merupakan salah satu alternatif untuk menggantikan media berbentuk teks (Suwarno, 2017, p. 1).
Sejumlah studi yang berkaitan dengan penggunaan video sebagai sumber belajar matematika pernah dilakukan. Dalam penelitian mengenai pengaruh media video youtube terhadap prestasi belajar matematika siswa kelas X SMK Negeri 2 Sukoharjo tahun ajaran 2017/2018 diperoleh hasil bahwa kelas yang menggunakan media video youtube ada pengaruh terhadap prestasi belajar matematika dibandingkan kelas yang menggunakan media pembelajaran papan tulis (Pambudi et al., 2018). Dalam penelitian yang dilakukan pada 31 siswa SMP Swasta Pemda Rantauprapat diperoleh hasil bahwa ada peningkatan respon siswa melalui penggunaan media video animasi dalam pembelajaran matematika yang ditandai dengan (1) siswa mendengarkan penjelasan pembelajaran menggunakan media; (2) siswa aktif dan tanggap dalam pembelajaran, siswa berani bertanya; dan (3) siswa berani menyampaikan pendapat. Pemanfaatan video dalam pembelajaran matematika cukup efektif digunakan dalam kelas virtual (Krisna \& Marga, 2018, p. 400). Hasil-hasil penelitian tersebut menunjukkan bahwa penggunaan video mendukung pencapaian hasil belajar dan performance siswa saat pembelajaran.

Pada semester genap tahun ajaran 2019/2020 guru pengampu mata pelajaran Matematika di SMK Negeri 2 Salatiga telah 
membuat sumber belajar virtual berupa video yang diunggah di aplikasi youtube. Video tersebut dibuat untuk memenuhi kebutuhan pembelajaran virtual pada materi statistika. Selama ini guru belum pernah melakukan pengkajian terhadap konten sumber belajar tersebut sehingga belum dapat diketahui kesesuaian dengan tujuan pembuatannya.

Berdasarkan kondisi tersebut, peneliti merasa perlu untuk melakukan penelitian mengenai analisis konten sumber belajar virtual berupa video yang digunakan dalam pembelajaran matematika materi statistika tersebut. Penelitian ini diharapkan dapat mengisi kesenjangan referensi mengenai analisis konten sumber belajar.

\section{METODE}

Penelitian ini merupakan studi kasus yang dilakukan pada bulan Agustus 2020 secara virtual. Penelitian dilakukan melalui tahap perumusan masalah, penyusunan instrumen, pengambilan data, analisis data, dan penyusunan laporan. Informan penelitian adalah guru Matematika SMK Negeri 2 Salatiga yang mengampu kelas XII sejumlah 1 orang. Data dikumpulkan melalui wawancara kepada informan dan telaah terhadap sumber belajar virtual berupa video. Instrumen yang digunakan dalam pengambilan data tersebut adalah pedoman wawancara dan pedoman telaah video. Analisis data dilakukan secara interaktif sebagai berikut:

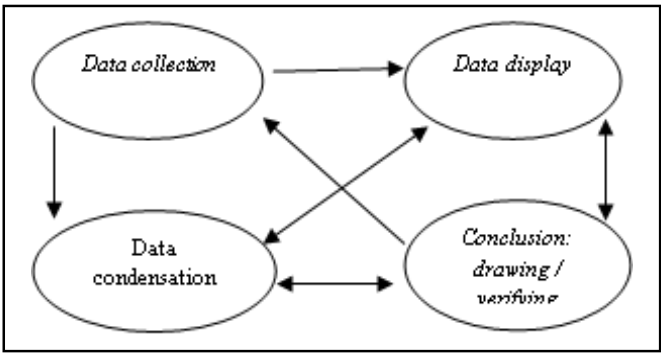

Gambar 1. Komponen Analisis Data Menggunakan Interactive Model (Miles et al., 2014)

Adapun pengecahan keabsahan hasil penelitian dilaksanakan melalui triangulasi.

\section{HASIL DAN PEMBAHASAN Hasil}

Topik pertama yang ditelaah dalam penelitian ini adalah sistematika video. Melalui telaah diketahui bahwa secara garis besar, video ini terdiri dari bagian pendahuluan, isi, dan penutup. Pada bagian pendahuluan, guru menyampaikan salam dan informasi mengenai materi pembelajaran yang akan disampaikan yaitu penyajian data. Bagian inti terdiri dari deskripsi kompetensi yang akan dicapai. Kompetensi yang akan dicapai melalui penggunaan video tersebut adalah kompetensi pengetahuan ( $\mathrm{KI} \quad 3$ ) dan kompetensi keterampilan (KI 4). Deskripsi kompetensi dasar pada video sebagaimana gambar berikut: 


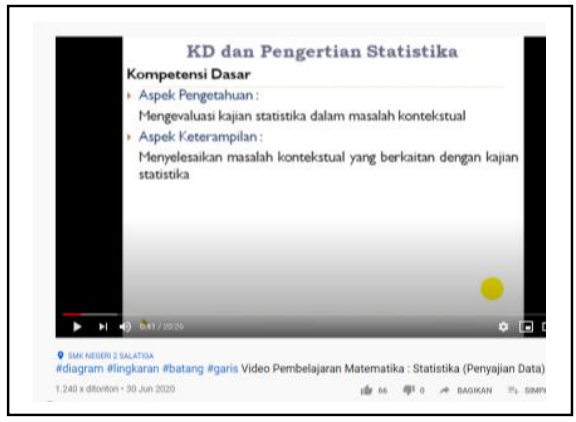

Gambar 2. Deskripsi kompetensi dasar

Setelah tampilan kompetensi, dalam video dipaparkan deskripsi materi penyajian data. Deskripsi materi meliputi definisi, objek statistika, jenis data, perolehan data, penyajian data. Berikut adalah salah satu tampilan deskripsi materi.

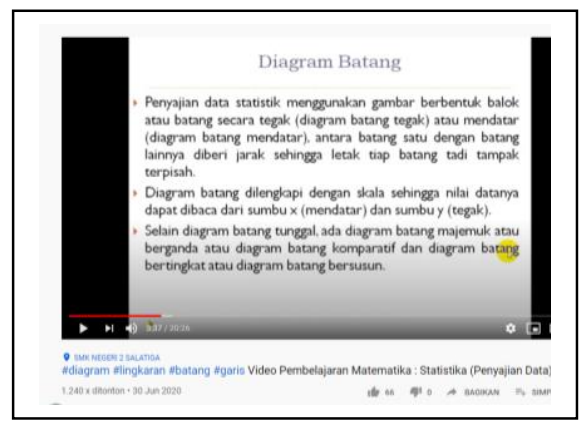

Gambar 3. Deskripsi materi

Dalam mendeskripsikan materi, guru menyajikan konsep lalu memberikan contoh penerapan konsep pada masalah matematis.
Masalah matematis dalam hal ini disusun dengan mengacu pada kompetensi dasar yang akan dicapai dalam pembelajaran. Berikut adalah salah satu contoh penerapan konsep penyajian data dalam masalah matematis.

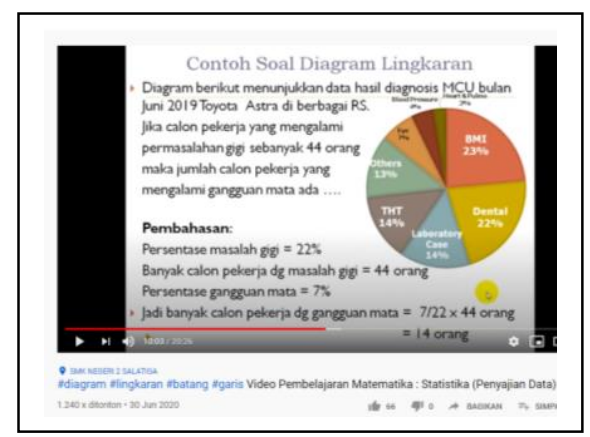

Gambar 4. Penerapan konsep untuk menyelesaikan masalah matematis

Setelah pemaparan konsep, contoh penerapan untuk menyelesaikan masalah matematis, guru memberikan masalah matematis untuk diselesaikan oleh siswa. Masalah matematis tersebut dimaksudkan untuk memfasilitasi siswa dalam menalar. Karena video ini diunggah di aplikasi youtube, siswa dapat menyampaikan solusi dari masalah matematis yang telah mereka selesaikan. Guru pun dapat memberikan umpan balik berupa ulasan terhadap benar atau tidaknya solusi tersebut, kalimat apresiasi, dan informasi untuk mengenai 
kegiatan belajar selanjutnya yang dapat dilakukan siswa.

Berkaitan dengan konten video guru menyatakan sebagai berikut:

"Video tersebut digunakan untuk pembelajaran materi statistika. Di dalamnya ada konsep, contoh, dan soal. Soal dapat dikerjakan pada kolom komentar. "(WN/Agustus 2020)

Guru juga menyatakan bahwa video ini digunakan untuk mencapai KD 3.27 yaitu mengevaluasi kajian statistika dalam masalah kontekstual dan KD 4.27 yaitu menyelesaikan masalah kontekstual yang berkaitan dengan kajian statistika.

Adapun topik kedua yang ditelaah dalam penelitian ini adalah karakterisrik video sebagai sumber belajar virtual. Dalam contoh penerapan konsep dan masalah matematis yang dipaparkan di video, semua menggunakan konteks yang dekat dengan kehidupan sehari-hari. Hal ini merupakan makna dari sumber belajar yang kontekstual. Dalam video dinyatakan bahwa contoh data cacahan adalah data tentang banyaknya pasien positif covid yang sudah sembuh di seluruh dunia atau di Indonesia. Dalam penerapan konsep penyajian data, contohnya penyajian data dalam diagram batang adalah diagram batang tegak tunggal tegak data pengguna media sosial sedunia. Hal ini tampak pada gambar berikut:

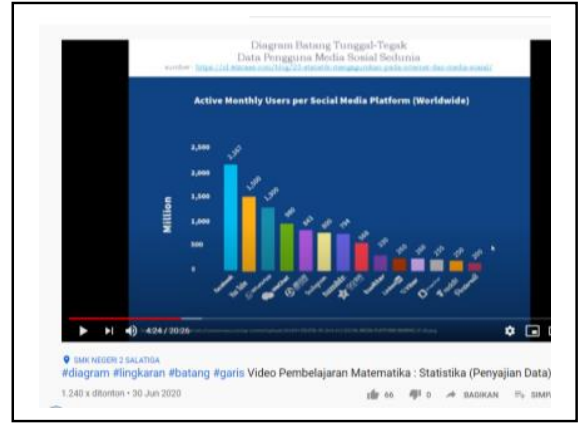

Gambar 5. Karakteristik kontekstual pada contoh penerapan konsep

Berkaitan dengan karakteristik kontekstual tersebut, guru menjelaskan:

"Saya susun demikian agar menyesuaikan dengan semangat Kurikulum 2013 dan pembelajaran kontekstual agar siswa memahami pentingnya materi statistika penyajian data. Ini juga sebagai upaya menghadirkan pembelajaran yang menarik minat peserta didik dengan contoh-contoh yang berkaitan dengan kehidupan di sekitar kita." (WN/Agustus 2020)

\section{Pembahasan}

Kemampuan guru dalam mendesain sumber belajar yang relevan dengan kompetensi yang akan dicapai merupakan hal yang penting dikuasai oleh guru. Dalam penelitian yang dilakukan oleh Fitrah ditemukan kondisi yaitu keterbatasan skill 
yang dimiliki oleh guru dalam pemanfaatan sumber belajar yang sesuai dengan kompetensi dasar(Fitrah, 2015, p. 883). Hal ini berarti bahwa guru perlu meningkatkan kompetensi perancangan sumber belajar yang tepat. Sumber belajar yang tepat dapat ditinjau dari kesesuaian dengan tujuan pembelajaran.

Ditinjau dari langkah-langkah pemaparan materi pada video tersebut diketahui bahwa video tersebut menggunakan model pembelajaran langsung (direct instruction). Hal ini ditandai dengan penyampaian definisi dan konsep, pemaparan contoh, dan pemberian masalah matematis. Hal ini sebagaimana sintaks pembelajaran langsung yang dikemukakan oleh Yusuf (Aini, 2017, p. 12) yaitu menyampaikan tujuan pembelajaran serta mempersiapkan siswa, mendemonstrasikan pengetahuan atau keterampilan, membimbing latihan, menelaah pemahaman, memberikan umpan balik, dan memberikan kesempatan kepada siswa untuk melakukan latihan dan penerapan selanjutnya.

Walaupun pembelajaran langsung identik dengan pembelajaran konvensional namun sejumlah penelitian menunjukkan bahwa pembelajaran langsung berdampak positif terhadap hasil belajar. Dalam penelitian di kelas VIII MTs NW Peneguk pada tahun pelajaran 2017/2018 diperoleh hasil bahwa penerapan model pembelajaran langsung menggunakan video dapat meningkatkan hasil belajar siswa (Aini, 2017).

Tentu saja pembelajaran langsung bukanlah satu-satunya landasan pedagogik yang bisa ditempuh. Penggunaan video pada youtube dengan pendekatan etnomathematics pernah diterapkan dalam penelitian di mana simpulannya adalah pembelajaran etnomatematika berbasis youtube dengan Corel Video Studio X10 berpengaruh positif terhadap pemahaman konsep siswa serta lebih baik daripada menggunakan pembelajaran konvensional setelah mengontrol kemampuan awal siswa (Nugroho et al., 2019, p. 96). Dalam penelitian lain, video difungsikan sebagai bagian dari pembelajaran berbasis Problem Based Learning (PBL) dengan simpulan bahwa menggnakan model PBL berbantuan media video dapat meningkatkan hasil; belajar matematika (Janah et al., 2019). Simpulan-simpulan penelitian tersebut menunjukkan bahwa video dapat diintegrasikan dalam model pembelajaran tertentu dan memberikan dampak yang positif terhadap hasil belajar siswa.

Kompetensi berkaitan dengan teknologi informasi dan komunikasi (TIK) juga sangat diperlukan khususnya dalam penyusunan sumber belajar virtual. Hal ini merupakan amanat perundang-undangan sebagai berikut: memanfaatkan teknologi informasi dan komunikasi untuk mengembangkan diri 
(Peraturan Menteri Pendidikan Nasional Nomor 16 Tahun 2007 Standar Kualifikasi Akademik Dan Kompetensi Guru, 2007).

Guru diharapkan dapat meningkatkan kompetensi berkaitan dengan penguasaan Teknologi Informasi dan Komunikasi (TIK) agar mendukung pembelajaran yang menarik, efektif dan efisien (Myori et al., 2019, p. 102). Pada era saat ini guru dituntut memiliki kemampuan lebih dalam hal pemanfaatan teknologi sebagai sumber pembelajaran (Wardinur \& Mutawally, 2019, p. 167). Keterampilan guru meliputi membuat dan memanfaatkan video dalam pengajaran merupakan salah satu prinsip yang perlu dipertimbangkan dalam pemanfaatan video dalam pembelajaran (Batubara \& Ariani, 2016, p. 47).

\section{Kesimpulan}

Kumpulan penelitian sejenis dapat dirujuk secara berkelompok. Untuk penelitian kualitatif, bagian hasil memuat bagianbagian rinci dalam bentuk sub topik-sub topik yang berkaitan langsung dengan fokus penelitian dan kategori-kategori.

\section{PENUTUP}

\section{Simpulan}

Berdasarkan hasil dan pembahasan diketahui bahwa video sebagai sumber belajar virtual materi statistika disusun berlandaskan model pembelajaran langsung (direct instruction). Pemaparan konten video dilaksanakan melalui menyampaikan kompetensi pembelajaran, memaparkan definisi dan konsep, menyampaikan contoh konsep dan penerapannya serta memberikan masalah matematis. Adapun sumber belajar virtual berupa video yang disusun oleh guru terdiri dari bagian pendahuluan, isi, dan penutup. Bagian pendahuluan memuat salam dan informasi mengenai materi. Bagian inti berisi deskripsi kompetensi pengetahuan dan keterampilan yang akan dicapai, deskripsi materi, contoh penyelesaian masalah, masalah matematis pada materi statistika. Adapun bagian penutup berisi informasi kompetensi yang akan dicapai pada pembelajaran selanjutnya, kalimat motivasi, dan salam. Karakteristik sumber belajar virtual materi statistika berupa video adalah kontekstual.

\section{Saran}

Dengan mempertimbangkan simpulan dapat disusun saran antara lain guru dapat mengembangkan sumber belajar virtual dengan model pembelajaran yang lebih beragam. Selain itu, penelitian ini dapat ditindaklanjuti dengan penelitian mengenai efektivitas penggunaan sumber belajar virtual. 


\section{DAFTAR PUSTAKA}

Abdulloh, A., Fahmi, M. Z., \& Siswanto, I. (2019). Penggunaan media sosial (youtube) sebagai media inovatif dalam pembelajaran di madrasah gresik. 5(1), 33-38.

Aini, R. (2017). Penerapan Model Pembelajaran Menggunakan Langsung Meningkatkan Hasil Belajar Kelas VIII pada Mata Pelajaran Biologi di MTs NW Peneguk Tahun Pelajaran 20172018. UIN Mataram.

Any, J. I. (2011). Pemanfaatan Sumbersumber Belajar dalam Proses Pembelajaran di SMP Negeri 2 Lebaksiu Kabupaten Tegal. Universitas Negeri Semarang.

Batubara, H. H., \& Ariani, D. N. (2016). Pemanfaatan Video sebagai Media Pembelajaran Matematika SD/MI. Muallimuna: Jurnal Madrasah Ibtidaiyah, 2(2), 47-66. https://doi.org/10.31602/muallimuna.v 2i 1.741

Fitrah, M. (2015). Kemampuan Guru Matematika dalam Mengelola Kelas Melalui Sumber Belajar untuk Memingkatkan Aktivitas Siswa. 833890. $\mathrm{h}$

Janah, F. N. M., Sulasmono, B. S., \& Setyaningtyas, E. W. (2019). Peningkatan Hasil Belajar Matematika Melalui Model Pembelajaran Problem
Based Learning Berbantuan Media Video Siswa Kelas IV Sekolah Dasar. Jurnal Pendidikan Dasar, 7(1), 63-73.

Peraturan Menteri Pendidikan Nasional Nomor 16 Tahun 2007 Standar Kualifikasi Akademik dan Kompetensi Guru, 1 (2007).

Krisna, F. P. P., \& Marga, M. H. P. (2018). Pemanfaatan Video untuk Pembelajaran Matematika Berbasis Masalah Kontekstual pad Topik Aljabar. Prosiding Seminar Nasional Ethnomatnesia, 400-405.

Miles, M. B., Huberman, A. M., \& Saldana, J. (2014). Qualitative (3th editio). SAGE publications, Inc.

Myori, D. E., Krismadinata, K., Hidayat, R., Eliza, F., \& Fadli, R. (2019). Peningkatan Kompetensi Guru dalam Penguasaan Teknologi Informasi dan Komunikasi melalui Pelatihan Pengembangan Media Pembelajaran Berbasis Android. JTEV ( Jurnal Teknik Elektro Dan Vokasional), 5(2), 102109.

https://doi.org/https://doi.org/10.24036/ jtev.v5i2.106832

Nugroho, K. U. Z., Widada, W., Zamzaili, Z., \& Herawaty, D. (2019). Pemahaman Konsep Matematika melalui Media Youtube dengan Pendekatan Etnomatematika. 04(01), 96-106. https://ejournal.unib.ac.id/index.php/jp mr\%0Apemahaman

Pambudi, R., Afghohani, A., \& Farahsanti, I. 
(2018). Pengaruh Media Video Youtube Terhadap Prestasi Belajar Matematika Pada Siswa Kelas X SMK Negeri 2 Sukoharjo Tahun Ajaran 2017 / 2018. Jurnal Pendidikan, 28(2), 175182.

https://doi.org/https://doi.org/10.32585/ jp.v28i2.345

Pamungkas, A. S., Ihsanudin, I., Novaliyosi, N., \& Yandari, I. A. V. (2018). Video Pembelajaran Berbasis Sparkol Videoscribe: Inovasi pada Perkuliahan Sejarah Matematika. Prima: Jurnal Pendidikan Matematika. https://doi.org/10.31000/prima.v2i2.70 5

Satriawan, S., \& Wutsqa, D. U. (2013). Keefektifan Pembelajaran dengan Sumber Belajar Interaktif Berbasis Komputer Ditinjau dari Motivasi dan Prestasi Belajar Matematika. Pythagoras: Jurnal Pendidikan Matematika, 8(2), 193-203. http://journal.uny.ac.id/index.php/pytha goras

Suwarno, M. (2017). Potensi Youtube sebagai Sumber Belajar Matematika. Pi:Mathematics Education Journal, 1(1), $\quad 1-7$. https://doi.org/https://doi.org/10.21067/ pmej.v1i1.1989

Wardinur, W., \& Mutawally, F. (2019). Peningkatan Kompetensi Guru Melalui Pelatihan Pemanfaatan Teknologi sebagai Media Pendukung Pembelajaran di MAN 1 Pidie. Jurnal Sosiologi USK, 13(2), 167-183. 